UNIVERSITY

OF DEBRECEN

FACULTY OF

HEALTH

NYÍREGYHÁZA

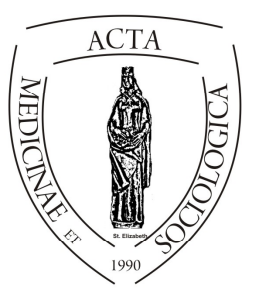

ACTA

MedSoc

VOLUME 8.

2017

\title{
100 fö alatti településeinkről népességföldrajzi aspektusból
}

\author{
Pásztor István
}

Debreceni Egyetem Társadalomföldrajzi és Területfejlesztési Tanszék

\begin{abstract}
According to the 2014 data in 154 Hungarian settlements live less than 100 inhabitants. As the result of the continuous demographic erosion some of the might face with total depopulation. Current study targeted to provide an overview about the demographic status of the smallest villages in North Eastern Hungary. Depopulating areas were drawn after the change of regime in the light of the study by the delimitation of the number of inhabitants. The investigation of the age structure, the calculation of the aging index and the analysis of the natural vital events demonstrated the actual demographic situation of each settlements.
\end{abstract}

Keywords: smallvillages, depopulation, agestructure, naturaldecrease, periphery

\begin{abstract}
Absztrakt. A 2014-es adatok szerint Magyarország 154 településén már a 100 főt sem éri el a lakosság száma. A folyamatos demográfiai erózió hatására néhányuk teljesen elnéptelenedhet. A tanulmány kiemelten Északkelet-Magyarország legkisebb falvainak demográfiai állapotfelmérését tüzte ki céljául. A létszámviszonyok alapján területi lehatárolást készítettem, amely kirajzolja, hogy a rendszerváltás után hol körvonalazódnak az elnéptelenedő térségek. A korszerkezeti vizsgálatokkal, az öregedési index számításával és a természetes népmozgalmi mutatók elemzésével pedig próbáltam rávilágítani az egyes települések aktuális demográfiai állapotára.
\end{abstract}

Kulcsszavak: törpefalvak, elnéptelenedés, korszerkezet, természetes fogyás, periféria

DOI: $10.19055 / \mathrm{ams} .2017 .8 / 25 / 2$ 


\section{Bevezetés}

Hazánkban a községek összesített népességszáma 1960-ban volt a legmagasabb, azóta folyamatos csökkenést tapasztalhatunk. Ez a tendencia 1990 után némileg mérséklödött, részben a szuburbanizáció, részben a városi ipari munkahelyek számának csökkenése és a közlekedési feltételek javulása következtében átalakuló vándorlási mérleg miatt. A területi különbségek azonban fokozódtak, elsősorban a perifériákon elhelyezkedő törpefalvak kerültek aggasztó helyzetbe. 2014-ben a TeIR adatai ${ }^{1}$ alapján 412 olyan település volt Magyarországon, melynek népességszáma nem érte el a 200 föt, ezek közül 154 (37,4\%) helyen a népesség száma 100 fó alatt maradt.

A „kétszámjegyü falvak” föleg Dél- és Nyugat-Dunántúlon és BorsodAbaúj-Zemplén megyében fordulnak elő. A kifejezetten törpefalvas térségek problémaköre igen komplex, ugyanis mélyen gyökerező társadalmi-gazdasági hátrányokkal néznek szembe. A tanulmányban igyekszem országos képet adni területi elhelyezkedésükről és számbeli változásukról. Északkelet-Magyarország legkisebb lélekszámú településeinek példáján keresztül az elnéptelenedés folyamatát, a korszerkezet változásait és az elvándorlás jelenségét vizsgálom közelebbről. A népességcsökkenést már érdemes a XX. század második felétől feltárni, mivel az erőteljes differenciálódás ekkor vette kezdetét és egyes települések (pl.: Gyürüfü, Szanticska) ekkor néptelenedtek el teljesen.

Az elemzéseknél főként a népszámlálásokból készített KSH statisztikákra és a TeIR adataira támaszkodom.

\section{A falufogalom, falutipizálás}

A falvaknak (községeknek) nincs általánosan elfogadott definíciója, mivel annak meghatározása a tudományos szemlélettől függ. Sőt több definíció ma már nem is helytálló, mivel a falvak szerepköre is állandóan változik és a korábban jellemző agrártevékenység már nem egyértelmüen jellemző. Leginkább úgy értelmezhetjük, hogy állandóan lakott települések, melyek nem rendelkeznek központi funkciókkal. Jellemzői pedig az alacsony lakosságszám, az emberek közötti szorosabb kapcsolat és a földszintes beépítés (Beluszky-Sikos, 1982; Mendöl, 1963).

A legalacsonyabb lélekszámú törpetelepüléseken pedig még könnyebben jelentkezhetnek a kedvezőtlen demográfiai és társadalmi folyamatok, vagy akár etnikai

\footnotetext{
${ }^{1}$ Azért a 2014-es adatokat használom, mert a tanulmány írásakor (2016. december, 2017. január) a teir.hu adatbázisában ezek voltak a legfrissebb vonatkozó információk.
} 
szegregációk kialakulásának is nagyobb az esélye. A törpe- és aprófalvakkal az utóbbi évtizedekben számos társadalomföldrajzi kutató (Mendöl Tibor, Erdei Ferenc, Enyedi György, Beluszky Pál, Frisnyák Sándor, Tóth József, Nemes Nagy József, Süli-Zakar István stb.) foglalkozott. A falvakat pedig többféle szempont alapján csoportosították (népességszám, hasznosítás-funkció, gazdasági szerepkör, a morfológiai jegyek számbavételével, a földrajzi fekvés szerint stb.). Az esetünkben fontos népességszám alapján a falvakat törpefalu (200fö alatt); aprófalu (200500 fö); kisfalu (500-1000 fö); középfalu (1000-2000 fö); nagyfalu (2000-5000 fö); óriásfalu (5000-10000fö) kategóriákra különítették el (Enyedi, 1980). Viszont ettől némileg eltérve csak a 100 fö alatti településeket vettem fel a vizsgálatba, mivel az elnéptelenedés közeli veszélye leginkább ezeket érintheti.

\section{0 fö alatti falvaink területi elhelyezkedése}

Az ország több térsége jellemezhető 100 fö alatti törpefalvas területekkel, amelyek nem arányosan oszlanak el az ország területén, mint ahogy az 1. ábra is mutatja.

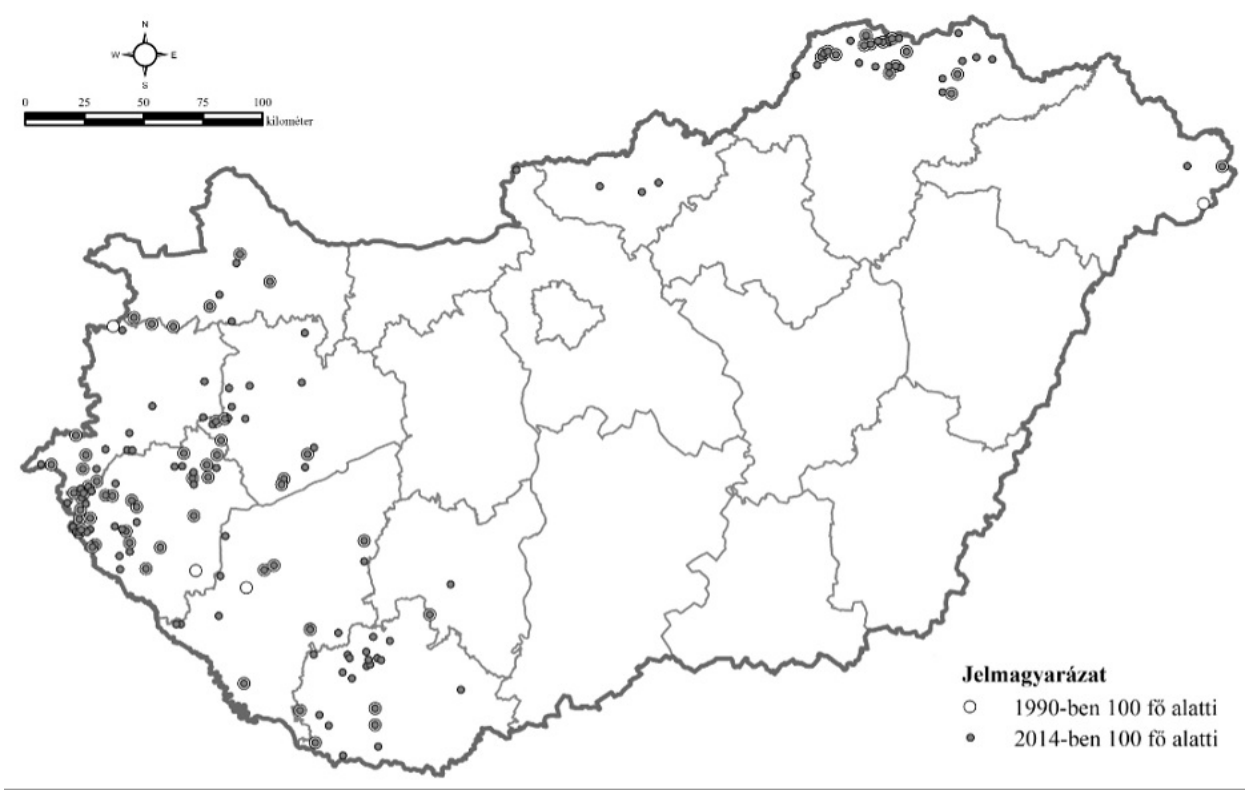

Forrás: saját szerkesztés a teir.hu adatai alapján.

1. ábra: 100 fö alatti települések elhelyezkedése Magyarországon (1990-2014). 
Ennek oka egyrészt a természetföldrajzi adottságokban rejlik, mivel a dombvidékek, a hegységek völgyei nem tették lehetővé nagyobb települések létrejöttét. Másrészt a kevésbé jó minőségü termőföld, a rossz közlekedési feltételek, a munkahelyek hiánya sem járult hozzá a népesebb közösségek tartósabb megtelepedéséhez (Horváth, 2013). A települési szintre számított népességszámmal súlyozott fejlettségi mutató szintén rámutat ezen térségek elmaradottságára. A jövedelmi periférián fekvő települések jelentős része is az aprófalvas térségekben koncentrálódik (Pénzes, 2015).

A rendszerváltás idején 72 település lélekszáma nem érte el a 100 föt, amely 2004-re 116-ra, majd pedig 2014-re 154-re emelkedett a TeIR adatai szerint (1. táblázat).

\begin{tabular}{|l|c|c|}
\hline \multicolumn{1}{|c|}{$\begin{array}{c}\text { Megyék, településszám } \\
\text { (2014) }\end{array}$} & $\begin{array}{c}\mathbf{1 0 0} \text { fö alatti település } \\
\mathbf{1 9 9 0}\end{array}$ & $\begin{array}{c}\text { 100 fö alatti település } \\
\mathbf{2 0 1 4}\end{array}$ \\
\hline Baranya (301) & 5 & 22 \\
\hline $\begin{array}{l}\text { Borsod-Abaúj-Zemplén } \\
(358)\end{array}$ & 15 & 30 \\
\hline Györ-Moson-Sopron (183) & 5 & 8 \\
\hline Somogy (246) & 6 & 12 \\
\hline $\begin{array}{l}\text { Szabolcs-Szatmár-Bereg } \\
(229)\end{array}$ & 2 & 2 \\
\hline Vas (216) & 7 & 16 \\
\hline Veszprém (216) & 5 & 15 \\
\hline Zala (258) & 27 & 44 \\
\hline Nógrád (131) & 0 & 3 \\
\hline Pest (187) & 0 & 1 \\
\hline Tolna (109) & 0 & 154 \\
\hline Összesen: $(2218$ település) & 72 & \\
\hline
\end{tabular}

Forrás: saját szerkesztés a teir.hu adatai alapján.

1. táblázat: 100 fő alatti települések megoszlása megyénként (1990-2014).

1990-ben még csak 4993 személy lakott 100 fönél kisebb településen, 2004-re ez a szám már 7489 fö, míg 2014-ben már közel tízezer (9815 fö). Lényegében az elmúlt 25 évben megkétszereződött azon személyek száma, akik ilyen falvakban élnek.

A vizsgált időszakban a Baranya megyei települések közül veszítettek legtöbben a népességszámukból, az érintett falvak 2014-es száma 4,4-szerese az 1990es értéknek. Legnagyobb arányban azonban Zala megyében (a települések 17,05\%-a) találunk 100 fó alatti falvakat.

A jelenség térbeli terjedését mutatja, hogy három megyével több került fel a megyei listára 2014-ben (1. táblázat). Nógrád megyéből immáron 3 település (Garáb, Debercsény, Kutasó) népességszáma sem éri el a 100 főt. Az egy településsel 
érintett Pest megyéből Tésa az Ipoly-mente legkisebb települése, míg Tolna megyéből a Tolnai-Hegyháton található Murga került fel a legkisebb népességszámmal rendelkezö falvak közé.

Az 1990-es települési adatsorból mindössze 5 olyan kisfalu (Nemeskisfalud, Komlódtótfalu, Ólmod, Ispánk, Zalasárszeg) van, amely nem került fel a 2014-es listára, mivel népességszáma elérte, vagy meghaladta a 100 föt. Az 1990-es listáról 60 településen viszont további népességcsökkenés történt. Ezt a sort a Zala megyei Lendvajakabfa vezeti, ahol a vizsgált időszakban a népességszám 69-röl 16-ra csökkent. Lendvajakabfa a XX. század elején még közel 400 fös település volt, az intenzív népességcsökkenése az 1950-es évektől kezdődött (www1).

A lista másik végén a szintén Zala megyei Gosztola található, amely ebben az időszakban több, mint megháromszorozta (18-ról 61 före) népességszámát. Gosztola ezt a növekedést egyértelmüen a turizmusnak köszönheti, hiszen komoly természeti vonzerővel és bőséges vadállománnyal rendelkezik (www2).

A három legkisebb népességszámú település sorrendje is teljesen kicserélődött az elmúlt 25 évben. 1990-ben még a Vas megyei Nemesmedves (16 fö) volt a legkisebb, majd ezt követte Gosztola és az Encsi járásban található Gagyapáti (19 fö). 2014-ben már a göcseji Iborfia (9 fö) volt a legkisebb, majd sorrendben két Borsod-Abaúj-Zemplén megyei kisközség, Gagyapáti (10 fö) és Tornakápolna (13 fö) követte. Nemesmedves 30 före növelte népességszámát, így a 2014-es listán már csak a 20. legkisebb volt.

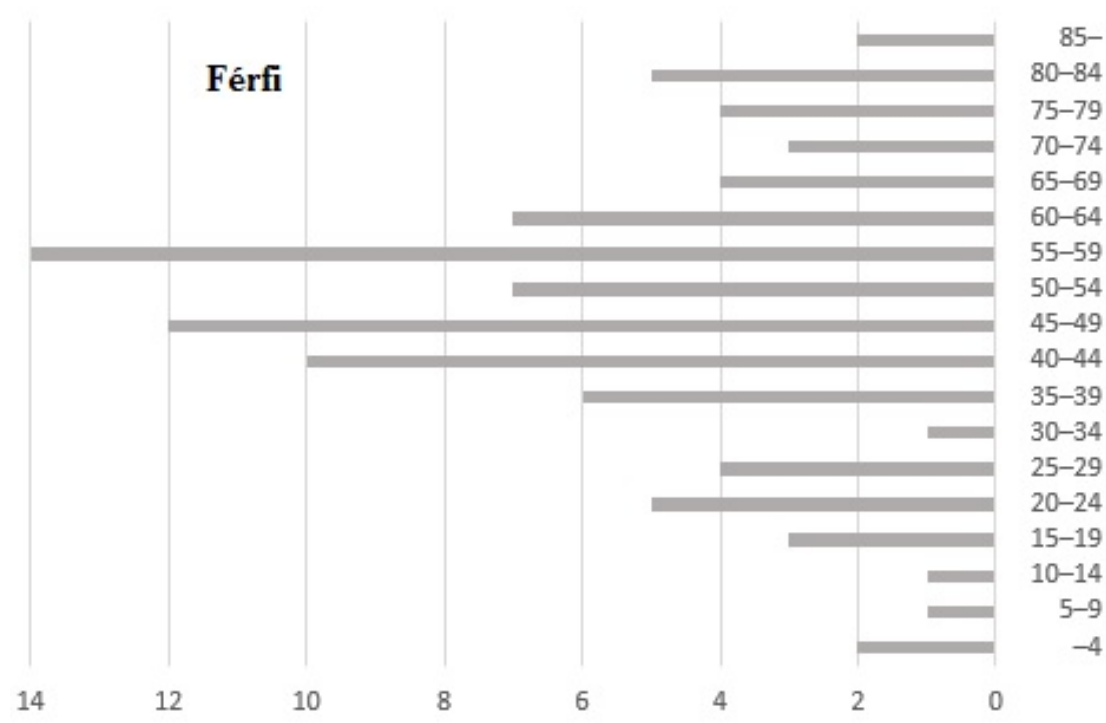

2/a ábra 


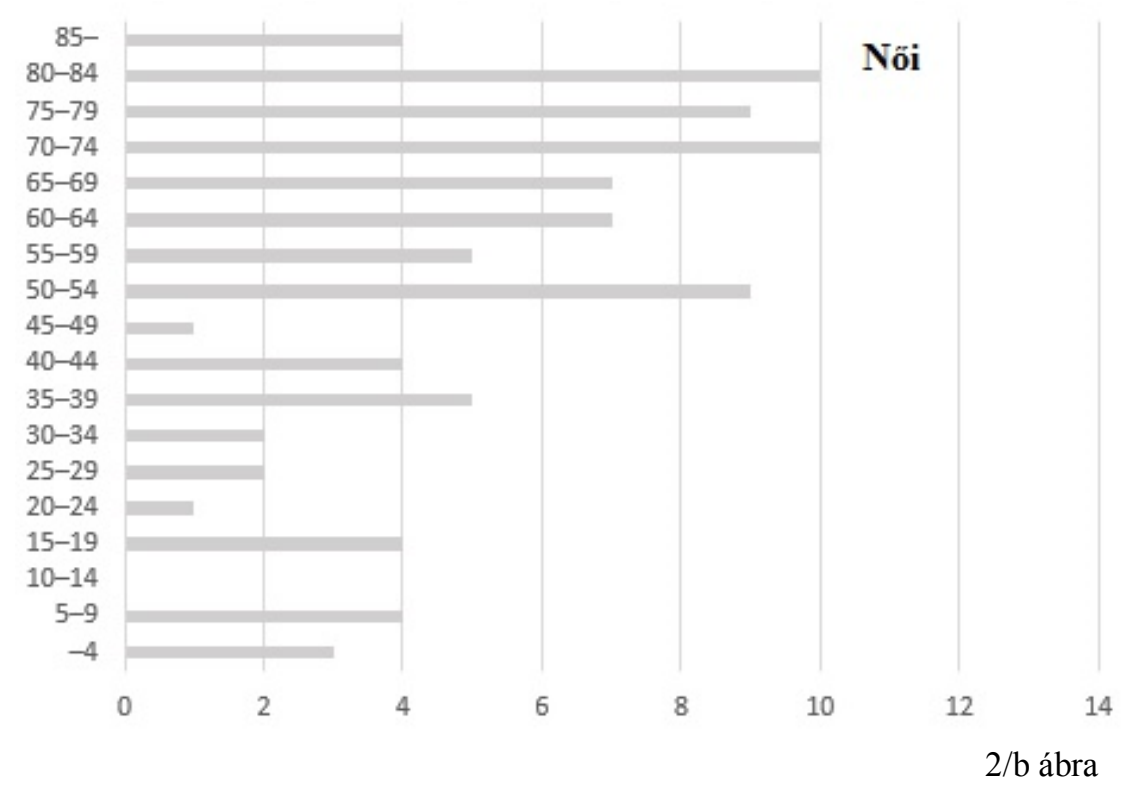

Forrás: saját szerkesztés a 2011-es népszámlálás adatai alapján

2. ábra: A 10 legkisebb népességszámú település összevont korfája, fő (2011)

A legkisebb lélekszámú településeken az elmúlt évtizedekben lejátszódó szelektív elvándorlás után újabban az elöregedés problémája jelentkezik (2. ábra). Ez pedig a természetes fogyás miatt hosszú távon a teljes elnéptelenedés veszélyével fenyeget (www3). Az 1. ábra mutatja, hogy ráadásul ez a probléma térben koncentráltan (Örség, Göcsej, Aggteleki-karszt) jelentkezik (Pénzes-Pásztor-Tátrai, 2015).

\section{Elnéptelenedő falvaink Északkelet- Magyarországon}

Északkelet-Magyarország hat megyéje közül három (Borsod-Abaúj-Zemplén, Nógrád, Szabolcs-Szatmár-Bereg) megyére, azon belül is föleg Borsod-Abaúj-Zemplén megye határmenti térségeire koncentrálódnak a törpefalvas területek (3. ábra). 


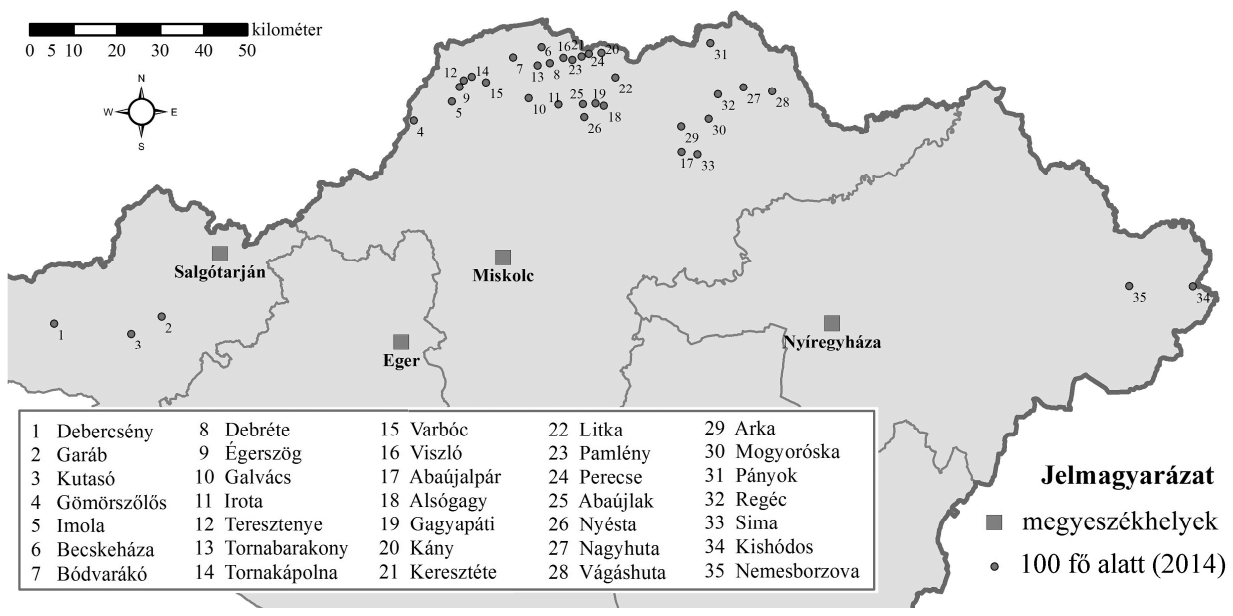

Forrás: saját szerkesztés a teir.hu adatai alapján

3. ábra: 100 fó alatti törpefalvak elhelyezkedése Északkelet-Magyarországon² (2014).

1990-ben még csak 17 db 100 fó alatti település volt (1. táblázat), addig 2014-re ez a szám már 35-re emelkedett. Így vizsgálatomba is ez a 35 törpefalu került bele. Az 1990-es adatsorból egyedül Komlódtótfalu nem szerepel a 2014-es listában. Az 1970-es nagy „Szamosi árvíz” szinte teljesen elpusztította a falut, s az akkori politikai vezetés megakadályozta, hogy a lakosság újjáépítse házait. Ezt követően a lakosok száma drasztikusan csökkent, s a 90-es évekre - a múlt század közepe táján még 1400 lakost számláló település - 67 fönyire zsugorodott (Dövényi, 2005 és www4). A jelenlegi növekedés a településre beköltöző zömében roma lakosságnak köszönhetö.

Komlódtótfalu mellett csak Sima tudta növelni népességszámát (22-röl 31 före), ami bizonyítja, hogy az elnéptelenedés a legkisebb falvakban tartósan fennálló jelenség. Arányaiban a legnagyobb népességvesztő település Becskeháza volt, amely a rendszerváltás óta elvesztette népességének majdnem 65\%-át. Ez a zsáktelepülés a KSH adatai szerint 1949-ben még 214 lakossal rendelkezett. A három legkisebb népességszámmal 2014-ben Gagyapáti (10 fö), Tornakápolna (13 fó) és Tornabarakony (18 fó) rendelkezett. Ezek a falvak is népesebbek voltak egykor, ezért érdemes nagyobb időmetszetben is vizsgálni a „legkisebbek” népességcsökkenési folyamatát.

\footnotetext{
${ }^{2}$ Északkelet-Magyarországon az Észak-magyarországi és az Észak-alföldi régiókat értem.
} 


\section{Az elnéptelenedés folyamata az 1950-es évektől napjainkig}

Az ötvenes évek szocialista településpolitikája életképtelennek minősítette az aprófalvakat, később az 1971-ben napvilágot látott Országos Településfejlesztési Koncepció pedig funkció nélküli településeknek tekintette ezeket, így lakóik tömegével hagyták el az ilyen falvakat (Bajmócy-Józsa-Pócsi, 2006). Az „optimális településméretet" el nem érő falvakban a tanácsok és az ellátó intézmények körzetesítésével, az állami beruházások minimalizálásával, a magánerős fejlesztések adminisztratív korlátozásával és számos egyéb módon alapvetően gátolták a törpe és aprófalvak fejlődését (Kiss, 2008). Mindez jelentős marginalizálódást is eredményezett /öregedő korszerkezet, alacsony iskolai végzettség, leromló lakókörnyezet, peremre szorult társadalmi csoportok megjelenése stb./ (Bajmócy-Balogh, 2002). A népességveszteség az elvándorlás mellett túlnyomórészt a természetes fogyásból is következett (Kiss, 2008).

Az elnéptelenedést erősíti, hogy ezeken a településeken élő emberek túlnyomórészt a jövedelmi periférián találhatóak. Azonban a nyugati határszél elaprózott településszerkezetü megyéiben, valamint Veszprém megyében az ebből fakadó probléma korántsem olyan súlyos, mint a Dél-Dunántúlon, illetve Északkelet-Magyarországon (Pénzes, 2010).

\section{0}

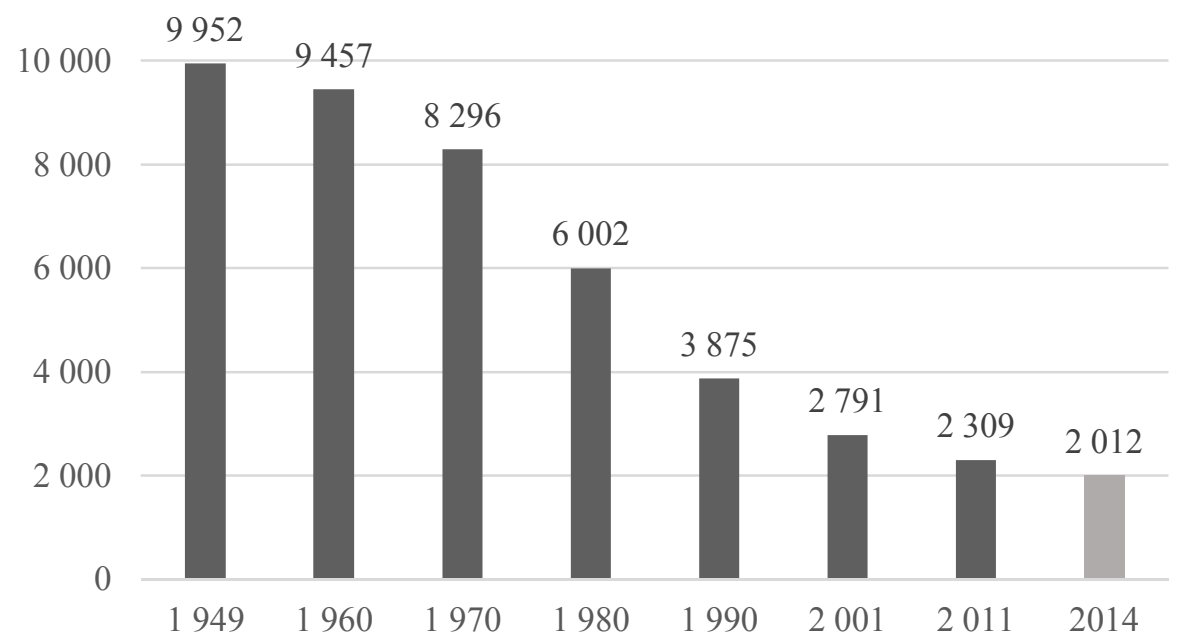

Forrás: saját szerkesztés a népszámlálások és a teir.hu adatai alapján.

4. ábra: A vizsgált 35 törpefalu összevont népességszámának alakulása (1949-2011). 
Az 1970-es évek településpolitikájának a vizsgált térségben több kicsi falu is áldozata lett, hiszen teljesen elnéptelenedtek. A központi szerepkör nélküli településekről gyakran kivonultak az addig jól müködő alapellátást biztosító elemek (általános iskola, müvelődési ház), a helyi közigazgatás szervezeti egységei fokozatosan leépültek (Makra, 2017). Ezekre a társadalmi-gazdasági hatású politikai döntésekre adott válasz a szelektív elvándorlás volt, melynek eredményeként helyben zömmel az idősebb, inaktív népesség maradt. A városcentrikus központi döntések nem vették figyelembe a helyi igényeket, az aktív korú falusi népesség kénytelen volt városokba, ipari centrumokba elvándorolni. A legnagyobb népességveszteség 1970 és 1990 között játszódott le, mely azóta mérsékeltebb ütemú, de továbbra is tart (4. ábra). A magyar településhálózat legkisebb elemei a szocializmus évtizedeiben az erőszakos beavatkozások miatt komoly településfejlesztési hátrányokat szenvedtek el, melynek demográfiai következményei máig hatóak.

A rendszerváltás és a fiatalok elköltözése után már inkább a természetes fogyás játssza a nagyobb szerepet a népességszám csökkenésében. 1990-ben már csak 29 élveszületés történt a vizsgált településeken, amelyekre 103 haláleset jutott. Napjainkban szintén hasonló a helyzet, mivel a TeIR adatai szerint 2014-ben a 35 településen 17 (13 településről) élveszületéssel szemben 56 haláleset (26 községből) történt. Debréte és Irota jelentette a két kivételt, mivel ott természetes szaporodást regisztráltak, mert haláleset nem történt, ugyanakkor született egy-egy gyermek. A jövőkép nagyon aggasztó, mivel a gyerekek több településröl szinte teljesen eltüntek: három törpefaluban (Debréte, Tornabarakony, Teresztenye Borsod-Abaúj-Zemplénből) egyáltalán nem élt gyerek (14 év alatti) 2011-ben.

\section{A szélsőséges korszerkezet}

Az elvándorlás következményeként elöregedő korstruktúra jött létre a törpefalvakban (Kovács, 2004). A demográfiai, korszerkezeti mutatók többségében a legkisebb falvak helyzete kedvezőtlenebb, mint az országos átlagok. Ettől a jellemzötől csak abban az esetben térnek el, ha általában jelentősebb számú roma lakos él a településen. A hazai cigányság gyermekvállalási hajlandósága ugyan csökken, de még mindig jelentősen meghaladja a nem romákra jellemző értékeket, illetve a cigány népesség átlagéletkora jóval alacsonyabb, mint az össznépességé (Kemény-Janky-Lengyel, 2004). A romák és nem romák között tapasztalható demográfiai különbségek a korfák alakjában jelentős eltéréseket eredményeznek.

Borsod-Abaúj-Zemplén megyében több olyan 2-300 fö közötti kistelepülés (pl.: Kiscsécs, Felsőregmec, Gadna) is előfordul, melyeknek korfáiban kirajzolódnak az említett jelenségek. 


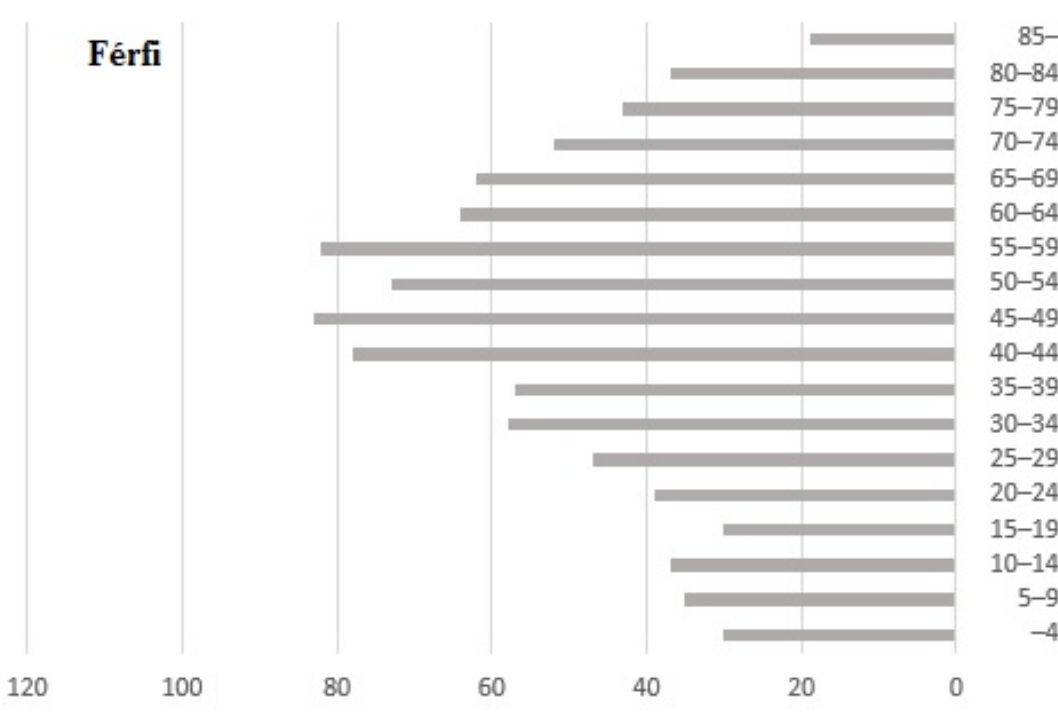

5/a ábra

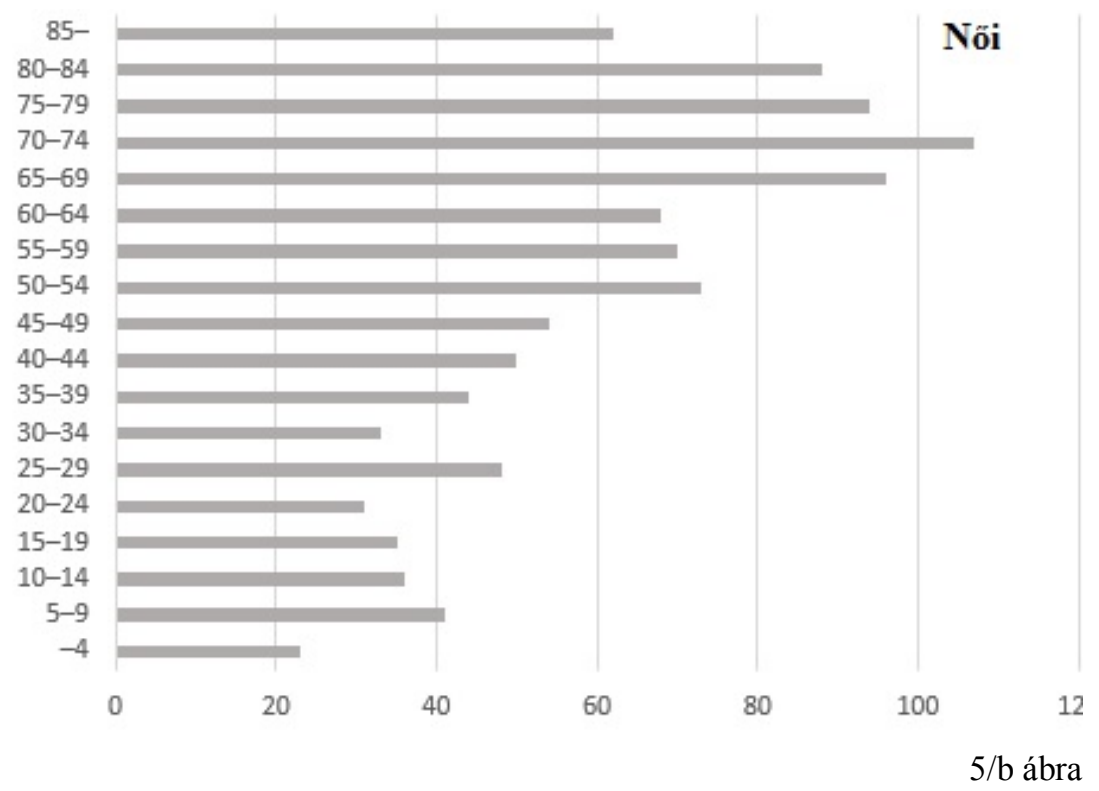

Forrás: saját szerkesztés a 2011-es népszámlálás adatai alapján.

5. ábra: A vizsgált északkelet-magyarországi települések összesített korfája, fő (2011). 
Ebben különösen érintett a Cserehát térsége, ahol már több 500 fö alatti településen (pl.: Csenyéte, Fáj) szinte csak roma lakos él (Baros-Pénzes-Tóth, 2007). Az a kérdés, hogy a még kisebb falvakban jellemző-e a romák olyan mértékủ megtelepedése, amely befolyásolhatja a korszerkezet összetételét.

A 35 település összesített korfájáról (5. ábra) leolvasható az elöregedő korszerkezet és az idősebb korosztályok túlsúlya. A fiatal és az idős generációk aránya kedvezőtlen irányba eltolódott. Egyre kevesebb a szülőképes korú nő, például Tornabarakonyban és Debrétén nem laknak 50 évnél fiatalabb nők. A gyerekek száma a rendszerváltás óta még kevesebb. Markánsan jelentkezik, hogy az idősebb korosztályokban a nők többségben vannak a férfiak magasabb halandósága miatt.

A jövőbeni tendenciákat is mutató öregedési index szerint 2014-ben a legroszszabb korszerkezeti összetétellel az Edelényi járásban lévő Varbóc ${ }^{3}$ rendelkezett. A kistelepülésen 1 fő 14 év alatti lakosra 20 fö 65 év feletti lakos jutott, így öregedési indexe: 2000. Nagyon rossz helyzetben van Becskeháza /szintén Edelényi járás/ (1500) és az Encsi járásban lévő Galvács (1200). A települések öregedési indexének átlaga: 535,4 .

A 14 év alatti lakosok száma csak a legkisebb Gagyapátiban és a Fehérgyarmati járásban lévő Kishódoson haladta meg a 65 év felettiek számát. Gagyapátiban (4 fö 14 év alatti és 2 fö 65 év feletti, index:50) ez egy tudatos építkezés, fejlesztés eredménye. A településen egyre több ingatlant vásároltak meg és turisztikai beruházásokat valósítottak meg és a lakosságnak számos kedvezményt biztosít az önkormányzat (www5). Kishódos (az ország legkeletibb települése) pedig a roma lakosság folyamatos beköltözésének köszönheti az index $(42,3)$ alacsonyabb értékét4.

Egy 2010-es becslés (Pásztor, 2013) szerint a 35 település közül Kishódoson a legmagasabb a roma lakosság aránya. Ezt követi a sorban Nyésta (roma arány: $35 \%$; öregedési index: 142,8) és Pamlény (roma arány: 28\%; öregedési index: $157,1)$, amely szintén a roma lakosság magasabb természetes reprodukciójának köszönheti a fiatalosabb korszerkezetét. A becslés szerint 22 településen nem található roma lakosság, de ahol nagyobb arányban jelen van ott jelentősen módosítja a korszerkezetet (6. ábra). Az ilyen falvakban az idősebb korosztályt a helyben maradó nem roma lakosok jelentik. A nem roma lakosság természetes fogyása miatt a romák aránya várhatóan még tovább emelkedik anélkül, hogy további beköltözéssel számolnánk.

A néhány lelkes településeken ritkább a romák megtelepedése. Ezt igazolja, hogy a 10 legkisebb falu közül (a becslés szerint) csupán kettőben éltek roma lakosok (Pásztor, 2013).

\footnotetext{
${ }^{3}$ Nem számítva Tornabarakony, Debréte, Teresztenye településeket, ahol 2014-ben nem volt 14 év alatti lakos.

${ }^{4}$ A DE Társadalomföldrajzi és Területfejlesztési Tanszékének 2016-os kutatásai alapján Kishódoson a lakosság kb. 45-50\%-a roma.
} 

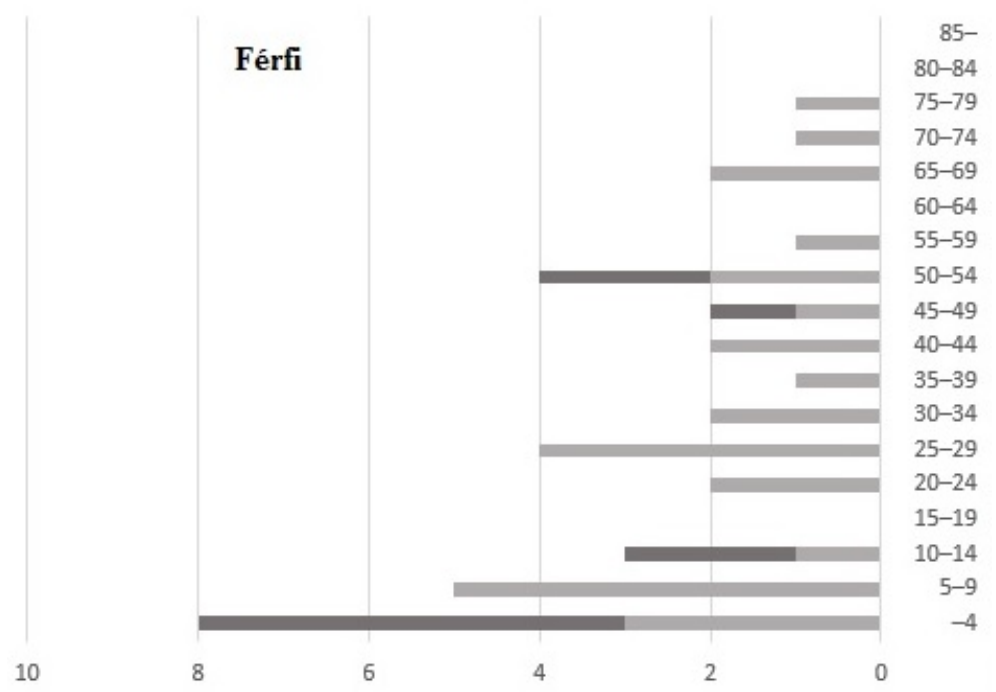

6/a ábra

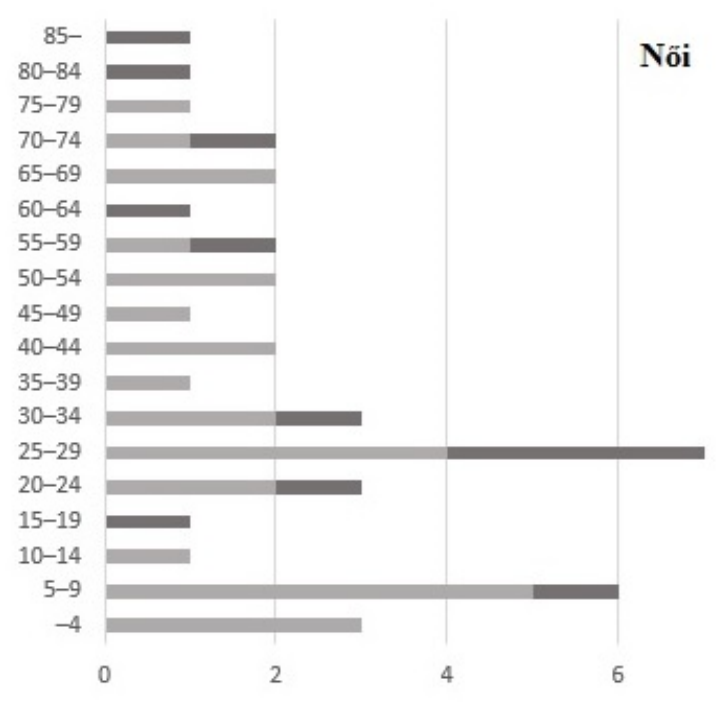

8

10

6/b ábra

Forrás: saját szerkesztés a 2011-es népszámlálás adatai alapján.

6. ábra: Kishódos korszerkezete és nemi megoszlása (2011). 


\section{Az elvándorlás és következményei}

A rendszerváltás idején az apró és törpefalvak vándorlási vesztesége a legnagyobb volt a település kategóriák között (Kovács, 1990). A jobb életfeltételek hiánya miatt legkisebb falvaink nem rendelkeznek népességmegtartó erővel. A falvak, kisebb városok talán legnagyobb problémája a folyamatos elvándorlás, amely elsősorban a fiatalabb korosztályokat érinti, így várhatóan a születések száma még tovább csökken és a természetes fogyás tovább erősödik. Ez helyben átalakítja a társadalmi szerkezetet és problémákat, feszültségeket teremt. Többek között ennek is köszönhető az átlagosnál jelentősen öregebb korstruktúra és a rosszabb természetes népmozgalmi mutatók.

Az intézmények számának redukálása, az intézményi ellátottság hiánya, a mezőgazdasági foglalkoztatottság csökkenése és a folyamatos funkcióvesztés csak erősíti a demográfiai folyamatokat.

A ,legkisebbek” közül csak néhány falunak sikerült a rendszerváltás után vándorlási nyereséget elkönyvelni. Az 1980-as években a vándorlási különbözet értéke mindenhol negatív tartományban maradt. Különösen kiemelkedett Vágáshuta (98\%o), melynek népességszáma is megérezte az intenzív elvándorlást, hiszen 1980ról 1990-re 270-röl 139 före csökkent. Azonban több törpefalu is (Galvács, Irota, Kány, Nagyhuta, Nemesborzova) -50\%o alatti értékkel szerepelt ebben az évtizedben. A legkisebb vándorlási veszteség (-6\%) Pamlény és Pányok községeket érte, ahol a nyolcvanas években még többen próbálkoztak gazdálkodással és állattartással, illetve az iparba irányuló nagyobb elvándorlás már korábban lejátszódott.

Az 1990-es évtizedben 11 település tudott vándorlási nyereséget felmutatni, melyek sorából kiemelkedik Regéc (17\%). Ebben nagy szerepet játszhatotta regéci vár régészeti feltárása és az ehhez kapcsolható általános fejlesztések. Viszont a nyolcvanas években még jól szerepelt Pányok (-40\%o) a lista végén zárt, mivel sokan felhagytak a gazdálkodással és elköltöztek.

A 2000-es évek végére a legnagyobb veszteséget a gazdasági fejlettségükben az országostól jelentősen elmaradó két régió, Észak-Magyarország és Észak-A1föld könyvelhette el (2013-ban mintegy 6000, illetve 5500 fövel csökkent a népességük a belföldi vándorlásból adódóan) (Bálint-Gödri, 2015). Az ezredforduló utáni első évtizedben már inkább csak azok a települések (Kishódos, Keresztéte) tudtak nagyobb vándorlási nyereséget elérni, ahová valószínüsíthetően roma családok költöztek be. A legkisebb falvakba (Gagyapáti, Tornakápolna) is történt odavándorlás, amely pedig már inkább a vidéki turizmusnak köszönhető. Az elvándorlás tekintetében a Gönci járásban található Arka vezeti a sort (-40\%o), amely természetes fogyással kiegészülve, ebben az évtizedben elvesztette népességének több, mint 40\%-át. 


\section{Összegzés}

A tanulmány konklúziója, hogy a legkisebb településeken a demográfiai problémák összetetten jelentkeznek és a folyamatos demográfiai erózió útjáról nem tudnak letérni. Ráadásul szoros összefüggések mutatkoznak más területekkel (pl.: jövedelmi periféria, szegregáció, marginalizáció, területi szegénység), amelyek csak erősítik a társadalmi perifériára való kiszorulást. A természetes fogyás, az elöregedés és az elvándorlás miatt tovább gyarapodhat az ,igazán kicsik” listája. A falvak és városok közötti erösödő területi különbségek hatására a népességcsökkenés még intenzívebbé válhat, az elnéptelenedés folyamata térben kiterjedhet. Több településen nem élnek 14 év alatti gyermekek, nincsenek szülőképes korú nők. A roma családok beköltözésével néhány helyen jobbak ugyan a mutatók, de a romákra jellemzö szociális hátrányok miatt ezek a települések sincsenek jobb helyzetben. A „legkisebbek számára” leginkább a vidéki turizmus jelenthet valami népesség-megtartó erőt és idézhet elő vándorlási nyereséget.

Ezek a törpefalvak viszont nincsenek abban a helyzetben, hogy mindezt önerőből meg tudják valósítani. Problémát jelent ugyanis az érdekérvényesítés gyengesége, az anyagi erőforrások és a humán tőke hiánya, valamint a helyi mezőgazdasági termelés átalakulása: a gépesítettség komoly munkaerő-kapacitásokat helyettesít; az állattartás és a tejbegyüjtés szinte teljesen eltủnt.

\section{Irodalomjegyzék}

1. Bajmócy Péter-Balogh András (2002): Aprófalvas településállományunk differenciálódási folyamatai. In: Földrajzi Értesítő 3-4. pp. 385-405.

2. Bajmócy Péter-Józsa Klára-Pócsi Gabriella: Szélsőséges aprófalvak. Aprófalvak a településlisták végein néhány társadalmi gazdasági mutató alapján. http://www.human.geo.u-szeged.hu/files/c/pocsi_gabi/2006_aprofalvaktelepuleslistak\%20vegein.pdf (Letöltve: 2016. 12. 28.)

3. Bálint Lajos-Gödri Irén (2015): Belföldi vándorlás. In Monostori Judit - Öri Péter-Spéder Zsolt (szerk.): Demográfiai portré 2015. KSH Népességtudományi Kutatóintézet, Budapest, pp. 171-186.Beluszky Pál-Sikos T. Tamás (1982): Magyarország falutípusai. MTA FKI, Budapest

4. Baros Zoltán-Pénzes János-Tóth Tamás (2007): Demográfiai folyamatok a Csereháton a XX. század folyamán. - In.: Migráció és asszimiláció Északkelet-Magyarországon és a Partiumban (1715-1992) (szerk. Demeter G. és 
Bagdi R.) StudiaHistorico-DemographicaDebrecina I., Kossuth Egyetemi Kiadó, Debrecen. pp. 170-185.

5. Dövényi Zoltán (2005): Az árvizek település- és településhálózat formáló hatása a Felső-Tisza vidéken. Földrajzi Értesítő 1-2. pp. 85-109.

6. Enyedi György (1980): Falvaink sorsa. Magvető Kiadó, Budapest

7. Horváth Eszter (2013): Kicsik között a legkisebbek - A törpefalvak sikerének kulcstényezői. Doktori értekezés, Győr.

8. Kemény István-Janky Béla-Lengyel Gabriella (2004): A magyarországi cigányság 1971-2003. Gondolat-MTA Etnikai-nemzeti Kisebbségkutató Intézet Budapest

9. Kiss János Péter (2008): Aprófalvasodás és aprófalvaink sorsa - történelmi metszetben. In.: Kistelepülések lépéskényszerben. Szerk.: Váradi Monika Mária, Budapest, Új Mandátum Kiadó, pp. 29-69.

10. Kovács Katalin (1990): Az urbanizáció alulnézetből. - In: Tóth J. (szerk.): Tér-Idő-Társadalom. MTA RKK, Pécs. pp. 272-303.

11. Kovács Tibor (2004): Aprófalvainkról - illúziók nélkül. Területi Statisztika, 7. (44.) 2. pp. 125-136.

http://rgdi.sze.hu/images/RGDI/honlapelemei/fokozatszerzesi_anyagok/horvath_eszter_disszertacio.pdf (Letöltve: 2016. 12. 27.)

12. Makra Zsófia (2017): A magyarországi törpefalvak népességszám változásának vizsgálata a közigazgatási önállóság tükrében. In.: Településföldrajzi tanulmányok 1. pp. 76-90.

13. Mendöl Tibor (1963): Általános településföldrajz. Akadémiai Kiadó, Budapest

14. Pásztor István Zoltán (2013): Társadalomföldrajzi vizsgálatok az északkeletmagyarországi cigányság körében (létszámváltozások, önkormányzatiság, kisebbségi választások). PhD dolgozat, kézirat.

15. Pénzes János (2010): Az Észak-alföldi régió periférikus térségeinek tagoló tényezői a rendszerváltás után, különös tekintettel a területi jövedelemegyenlőtlenségekre. - Doktori (PhD) disszertáció, DE TTK Földtudományok Doktori Iskola, Debrecen. $181 \mathrm{p}$.

16. Pénzes János (2015): A kedvezményezett térségek lehatárolásának aktuális kérdései. Területi Statisztika, 3. pp. 206-232.

17. János Pénzes-István Zoltán Pásztor-Patrik Tátrai (2015): Demographicprocesses of developmentallyperipheralareas in Hungary. Stanovništvo. 53/2. pp. 87-111.

18. www1: Lendvajakabfa népessége. http://nepesseg.com/zala/lendvajakabfa (Letöltve: 2016. 12. 28.) 
19. www2: Gosztola község története. http://www.gosztola.hu/tortenet.php (Letöltve: 2016. 12. 28.)

20. www3: Települések a lét határán. Erösen fogyó népességü törpefalvak Magyarországon.

http://www.ksh.hu/docs/hun/xftp/idoszaki/regiok/fogyonep.pdf (Letöltve: 2016. 12. 28.)

21. www4: Komlódtótfalu története. http://www.komlodtotfalu.hu/tortenet.html (Letöltve: 2016. 12. 28.)

22. www5: Egy apró gyöngyszem a Csereháton.

http://anotherlife2time.qwqw.hu/?modul=blog\&a=95580 (Letöltve: 2017. 01. 02.)

\section{Dr. Pásztor István}

Történelem-földrajz szakos középiskolai tanár, közigazgatási szakmenedzser, $\mathrm{PhD}$ fokozat földtudományok. Munkahely: Debreceni Egyetem Társadalomföldrajzi és Területfejlesztési Tanszék egyetemi adjunktus. 